\title{
The Biophilic Approach to Qualify the Inhabitant-Nature Relationship in the Domestic Space: The Case of the City of El Kala, Algeria
}

\author{
Fatima Zahra Djouad \\ Department of Architecture and Urban Planning, Faculty of Science and Technology, University \\ 8 Mai 1945, Guelma, Algeria
}

Received 2021-02-12, accepted 2021-09-24

\section{Keywords}

Algeria, biophilic design, domestic space, inhabitant, nature.

\begin{abstract}
El Kala is a city on the edge of eastern Algeria, located in an exceptional natural landscape, classified as a world biosphere reserve in 1990 by UNESCO. The diversity of nature within the domestic space leads to research and study its place and value for the inhabitants and encourages to think about how to qualify the relationship between inhabitants and nature through the domestic space. This study is based on a biophilic approach, adapted to the architectural scale, based on a landscape and architectural analysis. The results obtained show that the observed biophilic design is only a means to build a relationship with nature by the inhabitants. The objective of this article is to highlight the contribution of the biophilic approach in determining the behaviour of the inhabitants of the city of El Kala.
\end{abstract}

\section{Introduction}

There is a close connection between man and nature, often nurtured by the development of human needs in the many facets of life. This relationship that each individual has with nature is transposed to the city. It is created on different scales: the scale of the territory, spatial planning, urban composition and architectural space [1]. The relationship between man and nature is theorised by the biophilic approach and studied on an architectural scale by the presence of natural elements in construction according to three principles: nature in space, natural analogies, the nature of space [2]. Surrounded by forests and lakes, the town of El Kala is an example of the interaction between the urban environment and its natural surroundings. El Kala is located $20 \mathrm{~km}$ from the Tunisian border and $77 \mathrm{~km}$ from the city of Annaba, one of the main cities of eastern Algeria. Its position at the centre of a national park classified as a natural biosphere reserve in 1990 by UNESCO, gives it a special character in urban and architectural production.
Today, a progression of the city towards the forest area is observed, which results in a mixture of habitat and nature in its residual form (reeds, natural trees, cacti). For example, old trees can be seen in the domestic area, fences made of natural materials, gardens and openings to the surrounding landscape. This highlights the direct relationship of the inhabitant with nature. In this study, the aim is to answer the following question: How can we contribute to the qualification of the relationship between the inhabitant and nature through the design of his domestic space? The hypothesis formulated is that the presence of natural elements in the domestic space explains the inhabitants' attachment to nature in the design of their spaces, by understanding multiple biophilic behaviours. Thus, the aim of this article is to determine whether the biophilic approach can be adopted as an approach in architecture to interpret the relationship between inhabitant and nature through the relationship between domestic space and nature. 
TABLE I

\section{Nature Experiences}

Source: Kellert [9], [17], adapted by the author, 2020.

\begin{tabular}{|l|l|}
\hline Experience & Description \\
\hline Utilitarian & $\begin{array}{l}\text { The exploitation of nature's vast resources, } \\
\text { including food, } \\
\text { clothing, tools, medicine and shelter }\end{array}$ \\
\hline $\begin{array}{l}\text { Naturalist and } \\
\text { aesthetic }\end{array}$ & $\begin{array}{l}\text { A contact characterised by fascination, wonder } \\
\text { and admiration for the beauty and complexity } \\
\text { of nature and its diversity }\end{array}$ \\
\hline Ecological science & $\begin{array}{l}\text { Motivation to study biophysics systematically } \\
\text { model, structures and functions of the natural } \\
\text { world }\end{array}$ \\
\hline Symbolic & $\begin{array}{l}\text { Refers to the use of nature's symbols to } \\
\text { communicate }\end{array}$ \\
\hline Humanist & $\begin{array}{l}\text { A deep emotional connection with the sensitive } \\
\text { aspects of nature and its individual elements }\end{array}$ \\
\hline Moralist & $\begin{array}{l}\text { A strong sense of affinity and a sense of ethical } \\
\text { responsibility for the natural world }\end{array}$ \\
\hline Dominionistic & $\begin{array}{l}\text { The desire to master and control the natural } \\
\text { world, often associated with destructive } \\
\text { tendencies }\end{array}$ \\
\hline Negativistic & $\begin{array}{l}\text { The negative affect associated with nature } \\
\text { including fear, aversion and disgust }\end{array}$ \\
\hline
\end{tabular}

Human-Nature Relationship and Biophilia Hypothesis

In the first centuries, humans considered nature as a resource to meet their needs in terms of food, clothing, housing, etc. This vision of resource has evolved in parallel with human thought and needs. According to Scopelliti (2019), contact with nature has a positive impact on human health by reducing, according to the theories of attention restoration [3] and stress reduction [4], stress levels [5]. Nature, especially green nature, can play a key role as an environment that promotes health [6] and protects human life from climate disruption [7].

In 1993, Wilson introduced the theory of biophilia, based on the reality of the existence of genes and a behaviour of attachment to nature and natural processes by human beings [8]. In "The Biophilia Hypothesis" in 1993, Kellert determined human biophilic behaviour through a typology of interactions and experience of nature. The author identifies nine values recognised in Nature [9]. In an evolutionary process of the previous typology, Kellert in 2014 brought together the two experiences: aesthetic and naturalistic in a single heading (Table I).

\section{Biophilia in Urban Planning and Architecture}

Biophilic urban planning seeks to build a relationship between natural elements and the built environment [10]. In addition, it attempts to interpret the understanding of the biophilic approach in urban and architectural planning and design. At the building level, biophilic elements are

\section{TABLE II}

Principles of Biophilic Design Using Kellert's Typology

Source: Sevinç-Kayihan; Özçelik; Güney

[2], adapted by the author, 2020.

\begin{tabular}{|l|l|l|}
\hline Principles & Descriptions & Elements \\
\hline $\begin{array}{l}\text { Nature in space } \\
\text { (direct } \\
\text { experience } \\
\text { of nature) }\end{array}$ & $\begin{array}{l}\text { Real contact } \\
\text { with the natural elements } \\
\text { of the built environment }\end{array}$ & $\begin{array}{l}\text { Natural light, air, } \\
\text { vegetation, animals, } \\
\text { water, landscapes, } \\
\text { etc. }\end{array}$ \\
\hline $\begin{array}{l}\text { Natural } \\
\text { analogues } \\
\text { (the indirect } \\
\text { experience } \\
\text { of nature) }\end{array}$ & $\begin{array}{l}\text { Contact with the } \\
\text { representation or image } \\
\text { of nature, special } \\
\text { processes characteristic } \\
\text { of the natural world }\end{array}$ & $\begin{array}{l}\text { Images and works } \\
\text { of art, natural } \\
\text { materials, ornaments } \\
\text { inspired by forms } \\
\text { found in nature, etc. }\end{array}$ \\
\hline $\begin{array}{l}\text { The nature } \\
\text { of space } \\
\text { (the experience } \\
\text { of space } \\
\text { and place) }\end{array}$ & $\begin{array}{l}\text { Spatial features } \\
\text { of the natural environment } \\
\text { that have contributed } \\
\text { to the advancement } \\
\text { of human health and } \\
\text { well-being }\end{array}$ & $\begin{array}{l}\text { Prospect and refuge, } \\
\text { organised complexity, } \\
\text { integration of pieces } \\
\text { into sets, etc. }\end{array}$ \\
\hline
\end{tabular}

those that can be integrated on, in and around a building. At street level, these are the elements that can be integrated in and along streets, roads and pavements. At the scale of the village, they are larger in size and probably fewer in number [11]. In architecture, biophilic design serves to balance human needs with the value and considerations of natural environments and processes, and integrates the aspects and qualities of these elements into architectural design [2]. Table II summarises the principles of biophilic design using Kellert's typology.

\section{Biophilia as a Methodological Approach}

The biophilic approach has been adopted by researchers such as Simona Totafori (2020), to qualify the human-nature relationship in urban space. The benefits of biophilic design in the urban environment has been achieved using qualitative methodologies, to identify the ways in which the relationship between the built space and the natural landscape is perceived [12]. This paper focuses on the first principle of biophilic design: nature in space. It is defined by its elements: vegetation, water, landscapes, etc. As an architectural space, we have chosen the domestic space "delimited by the very institution of the morphological container (the dwelling unit such as the house, the apartment)" [13], [2]. In other words, the relation inhabitant / nature is qualified through the relation domestic space / nature according to the two formulas: use and visual contact [14]. The latter requires an analysis to detect possible views of the natural environment of the city.

Characterization of the Natural Landscape of El Kala

In this study, the landscape analysis is essentially based on the decomposition of the landscape into entities or units 
according to the following criteria: colour and land use (dark green: forest) [15]. The satellite image constituted the main background for this operation. This analysis is complemented by another visual analysis taking views through multiple points in the urban space, to identify the major landscape units visible from the city of El Kala [16].

\section{Relationship between Domestic Space and Nature}

This paper provides an overview of the context of the production of domestic space by professionals in urban space. The aim is to draw conclusions about the reality of the presence of a biophilic design which they have foreseen. The two steps in this process are first of all a determination of the place of nature in the domestic space by the professionals of urban space. It is based on an identification of the place accorded to natural elements in the preparation of subdivision plans, specifications, subdivision permits and architectural dossiers.

The self-built house was chosen, because it can inform us about the biophilic design chosen and conceived by the inhabitant without any influence of the urban and architectural space professionals. Records of 4 cases of selfbuilt houses located in the urban space of the city of El Kala were taken. The second stage is the determination of the relationship between domestic space and nature. Readings of 4 cases of self-built houses were taken to analyse the way in which nature presents itself in the domestic space through the ground plan (use) and the facade (visual contact with the surrounding landscape). The aim was to generalise the cases analysed to those observed. The observed cases correspond to 535 constructions out of a total of 5347 dwellings constituting the housing stock of the city of El Kala according to the last world population and housing census of 2008, i.e., a percentage of $10 \%$.

\section{Biophilic Behaviour of the Inhabitant}

The biophilic behaviour of the inhabitants of self-built houses was identified, to assess their relationship with the natural elements. The method is based on a comparison between the results obtained from the architectural analysis and Kellert's typology [17].

\section{Results and discussion}

Landscape Entities of the Natural

Figure 1 presents a photo-interpretation of the landscape characteristics of the natural environment of the city of El Kala. It is the result of the landscape analysis adopted as a tool to decompose the natural and urban landscape into entities. It was chosen to show the landscape entities which have a certain peculiarity. The forest entity represents the majority of the surrounding nature, varying according to its plant components: eucalyptus, Zen oak (boulif), maritime pine and Aleppo pine. The maquis entity represents bushy areas with a height of $0.4 \mathrm{~m}$ to $0.7 \mathrm{~m}$. The agricultural space entity reflects a form of human-made green nature, surrounding the city of El Kala especially in the southern and south-western areas.

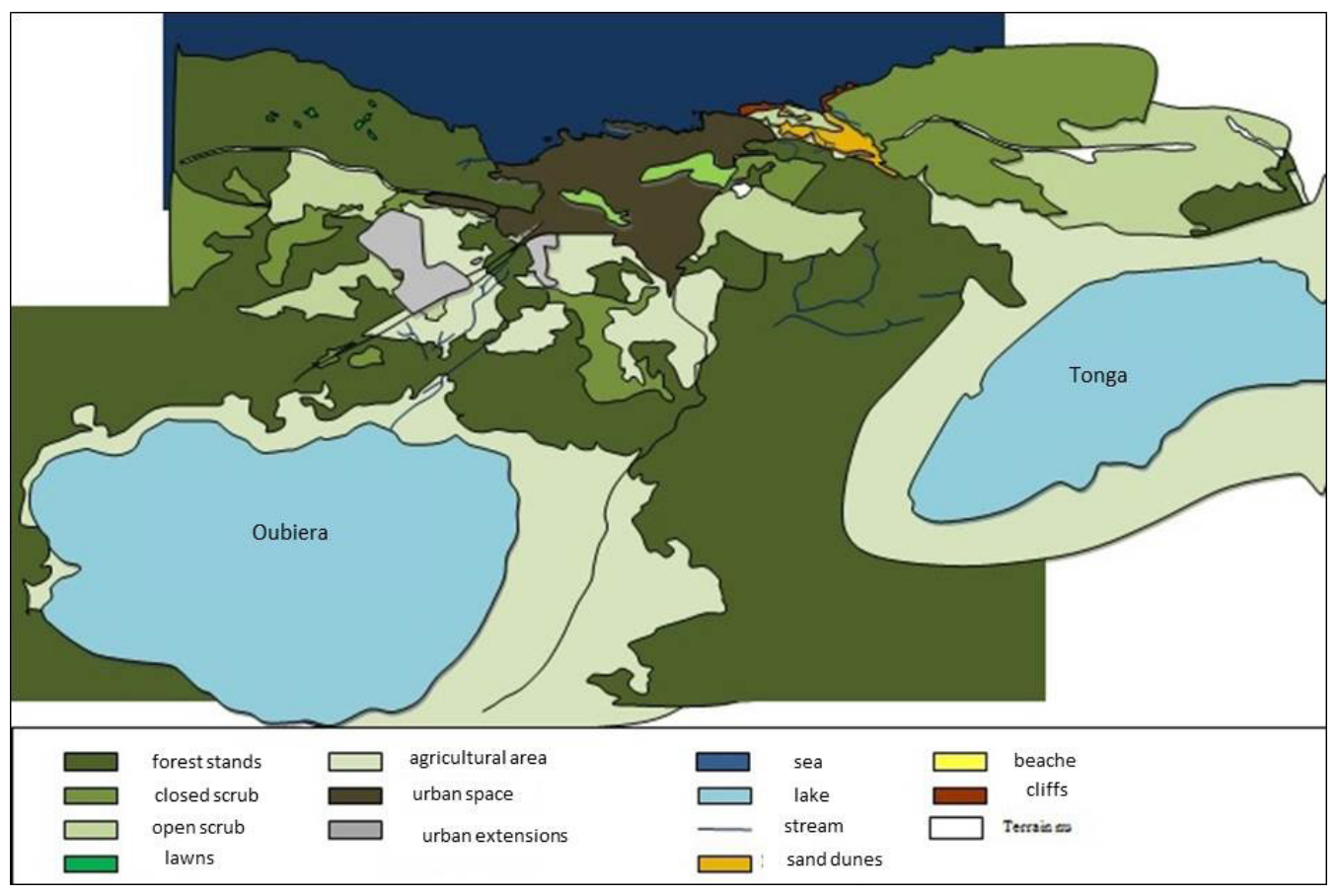

Fig. 1. Landscape features of the natural environment of the city of El Kala. Source: Author, 2020 and [18]. 


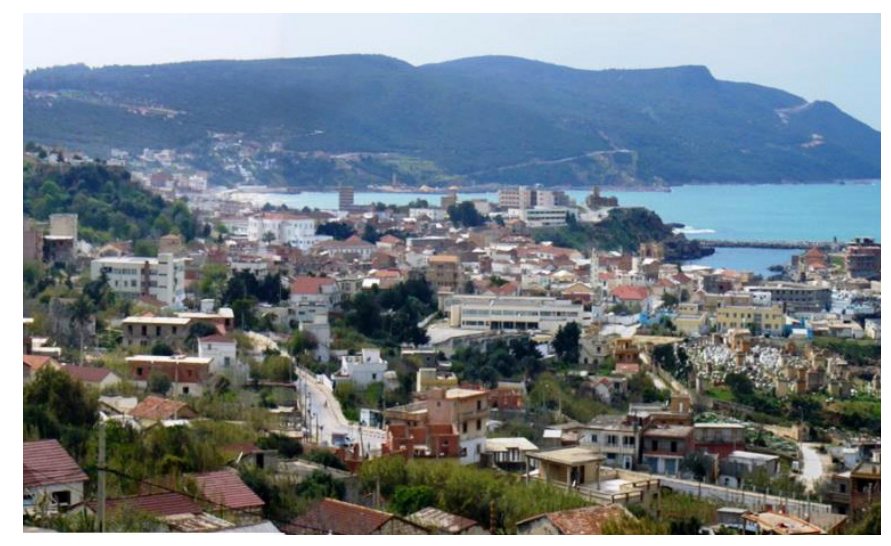

Fig. 2. Urban landscape of El Kala. Source: Author, 2019 and [19].

Then, the sea entity represents the coastline of El Kala, which extends for about $50 \mathrm{~km}$ between Cap Segleb (or Cap Roux) and Cap Rosa. It includes coral formations sheltering several species of fish. As far as the lake entity is concerned, it is composed of three large lakes of international importance: Mellah, Tonga, and Oubiera. The sand dune entity is illustrated by a dune barrier which adds another value to this environment, namely the fixation of the coastal dunes. Finally, the seaside entity consists of the beaches of El Kala and its natural creeks of exceptional beauty: Messida and the old Calle.

The rugged site of the town of El Kala offers panoramic views of nature (Fig. 2). The visual openings to the sea rival those to the forest and maquis features. Sometimes, the observer is surprised by the presence of the marine panorama. The blue open space is visible from most of the urban space. There are also several visual escapes to Lake Oubiera, from the housing estates of M'ridima, Boulif and Gelas (to the south at the south-west access to the city).

The Place of Nature in the Domestic Space in El Kala

A limited place is given to nature in the domestic space by urban space professionals. As the urban development of the city of El Kala is essentially based on the housing estate model. This model is made up of a set of lots resulting from the division of land in order to receive buildings for residential use. The appearance of self-building was the expected result, like all other Algerian cities. The city of selfbuilding is the result of the meeting between public policies and spontaneous urbanisation [20]. Self-built individual housing is the result of a legal vacuum, the building permit

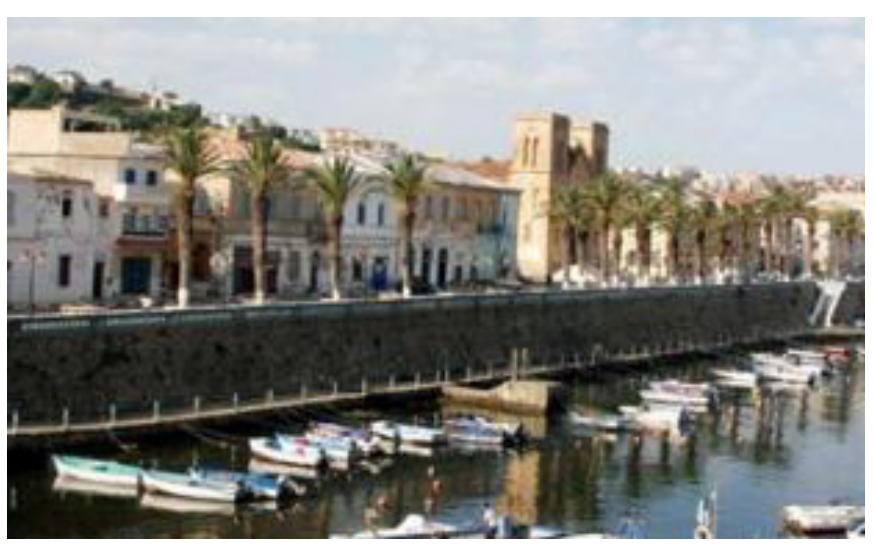

is reduced to an administrative authorisation that is rarely respected, the owners proceeding to multiple changes and building finally without reference to the established plans. Consequently, the state promulgated law 08-15 of 20 July 2008, fixing the rules for bringing constructions into conformity and their completion to put an end to this phenomenon [21].

As the urban development of the city of El Kala is mainly based on the housing estate model, it was aimed to highlight the relationship of urban space professionals with the natural elements. To this end, a more detailed study was carried out to examine the Gelass-South residential complex, which is in its realisation phase involving a prescription on an architectural scale. This allotment is intended for a construction project of 150 platforms. The terms of reference for this allotment are summarised by a site coverage of 0.32 . The natural elements that make up the allotment are a strip of vegetation, which limits the allotment on the east side. It consists of an assembly of natural and planted trees, covering a green space planted with benches. The low planted vegetation also occupies some voids in the middle of the subdivision, the bare ground is present in the north, forming the empty pockets. The forest remains a natural boundary for this allotment on the west side.

The architectural aspect of the typical construction proposed for this allotment refers to various considerations of nature:

- nature in the unbuilt space of the allotment: it remains empty, the architect did not try to transform it into a natural space, for example into a garden, even for aesthetic reasons;
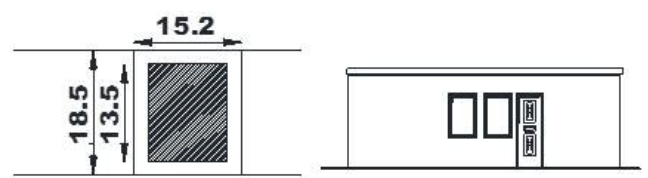

Main facade

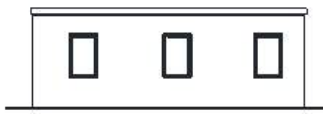

Back facade

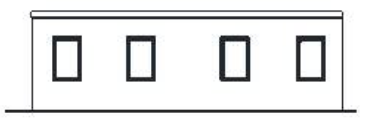

Side facade
Fig. 3. The architectural design of a typical house in Gelass-South. Source: The architectural file of the 150 platforms in Gelass-South. 


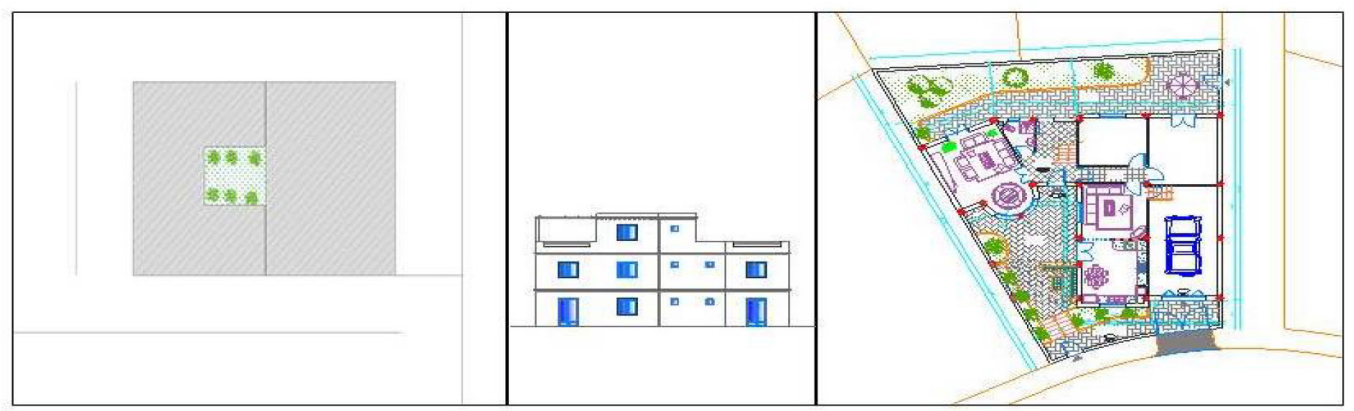

Fig. 4. Examples of biophilc designs by the architect. Source: Salah-Salah Hana, 2013.

- visual contact with the natural environment: the facades are devoid of any landscape or architectural treatment, and they do not take nature as an opening factor (Fig. 3).

At this stage the landscape aspect is no longer present in the building or subdivision planning permission. The unbuilt space remains undefined and is, therefore, left to the initiative of the inhabitants to transform it into gardens, or they add high metal fences, but without using it for construction. Thus, the relationship between the inhabitant and nature occupies a privileged place in the domestic space. When given the opportunity, the inhabitant constructs the domestic space in which he/she lives, usually by himself/herself, according to his/her culture, practices and relationship with the natural environment. In other cases, architects create biophilic designs that are appreciated by the inhabitants who keep them unchanged, such as: gardens, patios, and terraces that overlook the outside environment (Fig. 4).

The Inhabitant as a User of Nature

When given the opportunity, the inhabitant constructs the domestic space, in which he or she lives, generally by himself or herself according to his or her culture, practices and relationship with the natural environment. Inhabitants integrate nature, more precisely vegetation, around their private spaces [22] with multiple designations (gardens,
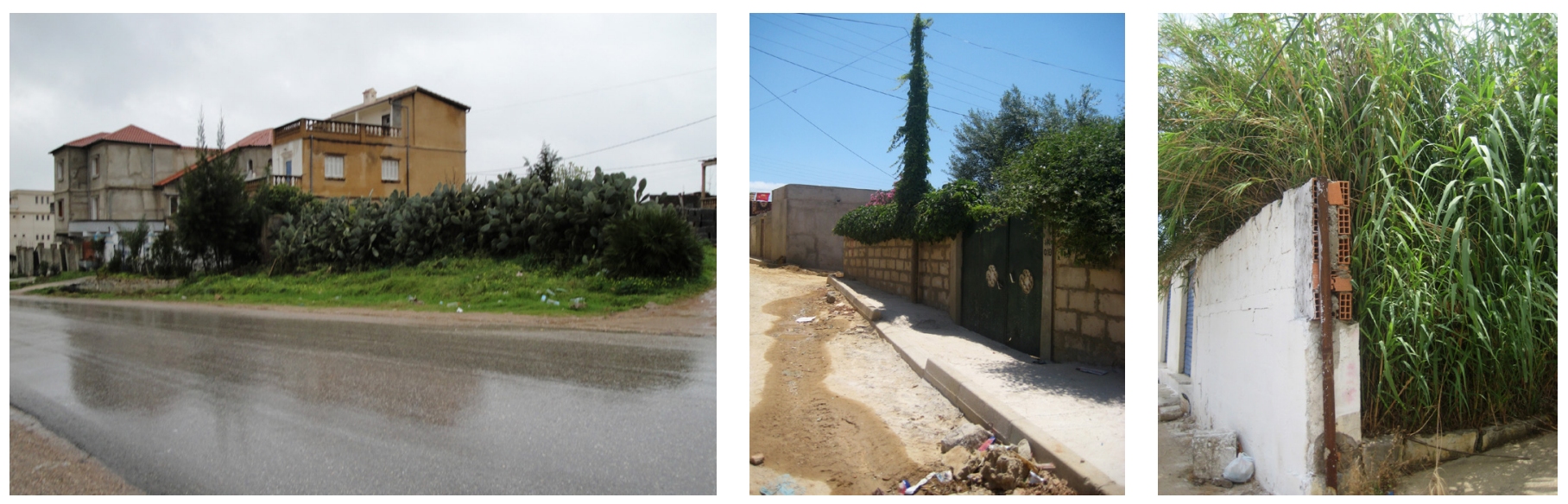

Fig. 5. Natural fences. Source: Author, 2019.
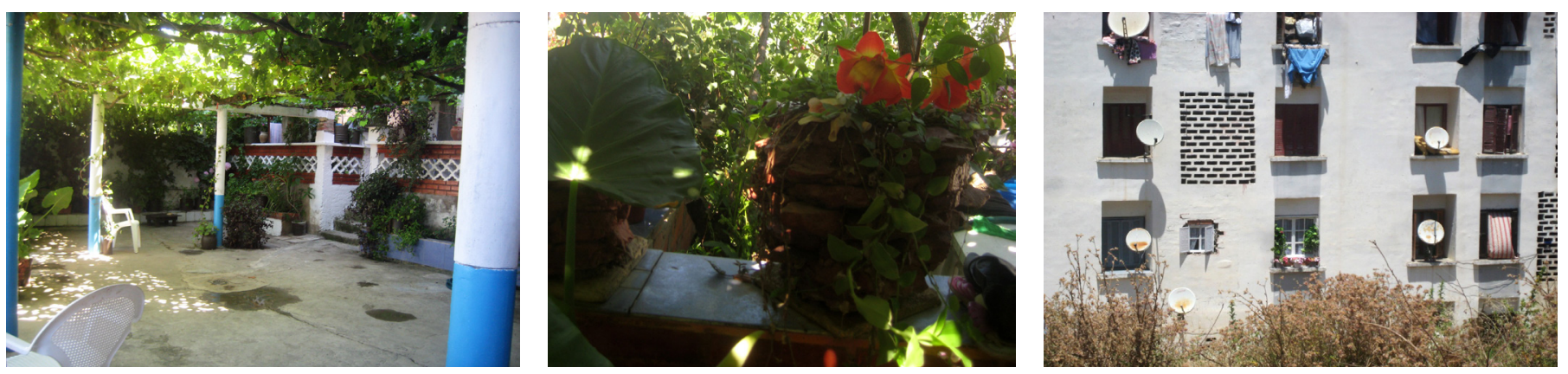

Fig. 6. El Aricha, and the stone pot. Source: Author, 2019.

Fig. 7. Window decorated with flowers. Source: Author, 2019. 
vegetable gardens or orchards) according to the surface area of the non-built space. To protect their properties, the inhabitants build high mineral fences combined with other naturals, such as reeds. They can also be exclusively natural (cactus) (Fig. 5). The non-built space is sometimes covered by a good assemblage of climbing plants: a perfectly organised vineyard surrounding a space laid out with tables and chairs surrounded by flower pots. Some inhabitants use stone in the construction of pots and jugs with a good composition of primary materials (Fig. 6). Inhabitants of collective buildings in the city of El Kala sometimes decorate their windows with pots of flowering plants and sometimes with bird cages (Fig. 7).

With regard to the visual contact of the inhabitant with the natural environment, we analysed several cases (Fig. 8). Case 1 is a visual opening to natural environment. The construction studied overhangs its environment, giving views of a mosaic of natural elements: sea, lake, forest, scrub and agricultural space. Case 2 represents visual contact with a particular natural landscape. In the middle of the Boulif, the case demonstrates how the inhabitant chose the visual contact with the sea over that of a forest remnant. Then, Case 3 shows a situation without visual contact with the natural environment. This case has two sub-cases: with or without choice. For the sub-case with choice, the example is a construction with introverted facades, located on the housing estate on the ridges on a gentle slope, surrounded by other constructions. For the sub-case without choice, the example chosen is a building in the Fernana 1 housing estate, surrounded by several

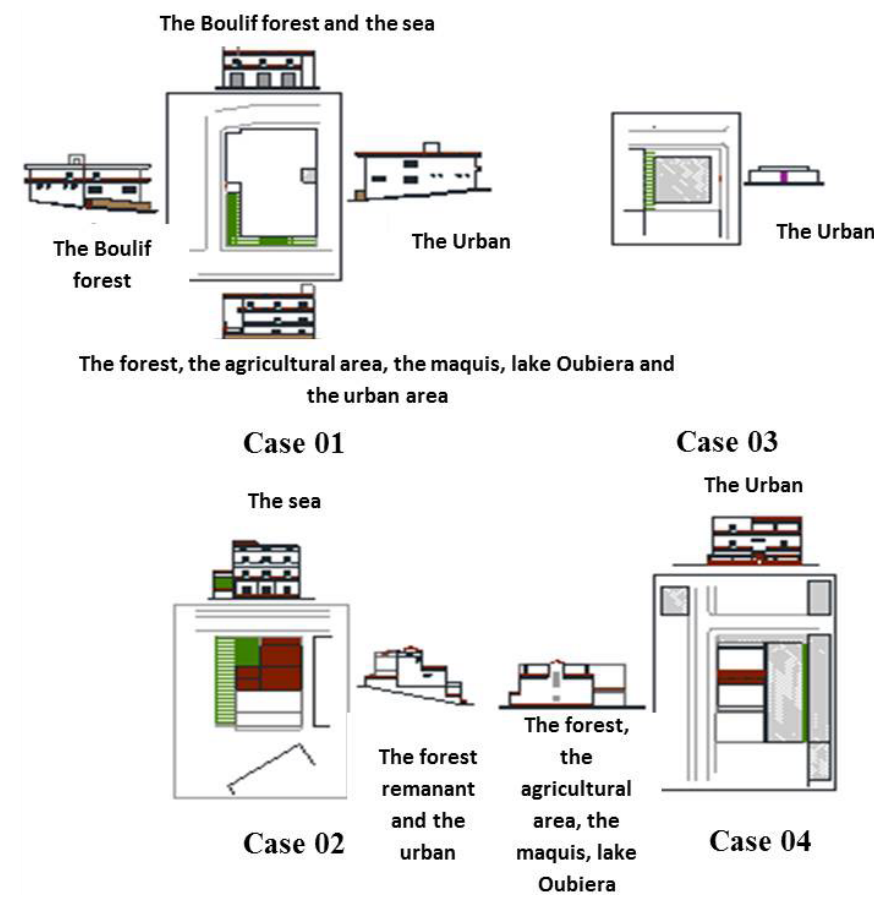

Fig. 8. Cases studied. Source: Author, 2020.

dwellings separated from the north and east by two lanes. This case includes all the constructions that do not have any visual contact with the surrounding landscape due to urban and topographical constraints. Finally, Case 4 shows a choice of visual contact with the urban rather than with nature. The selected construction is located at the western

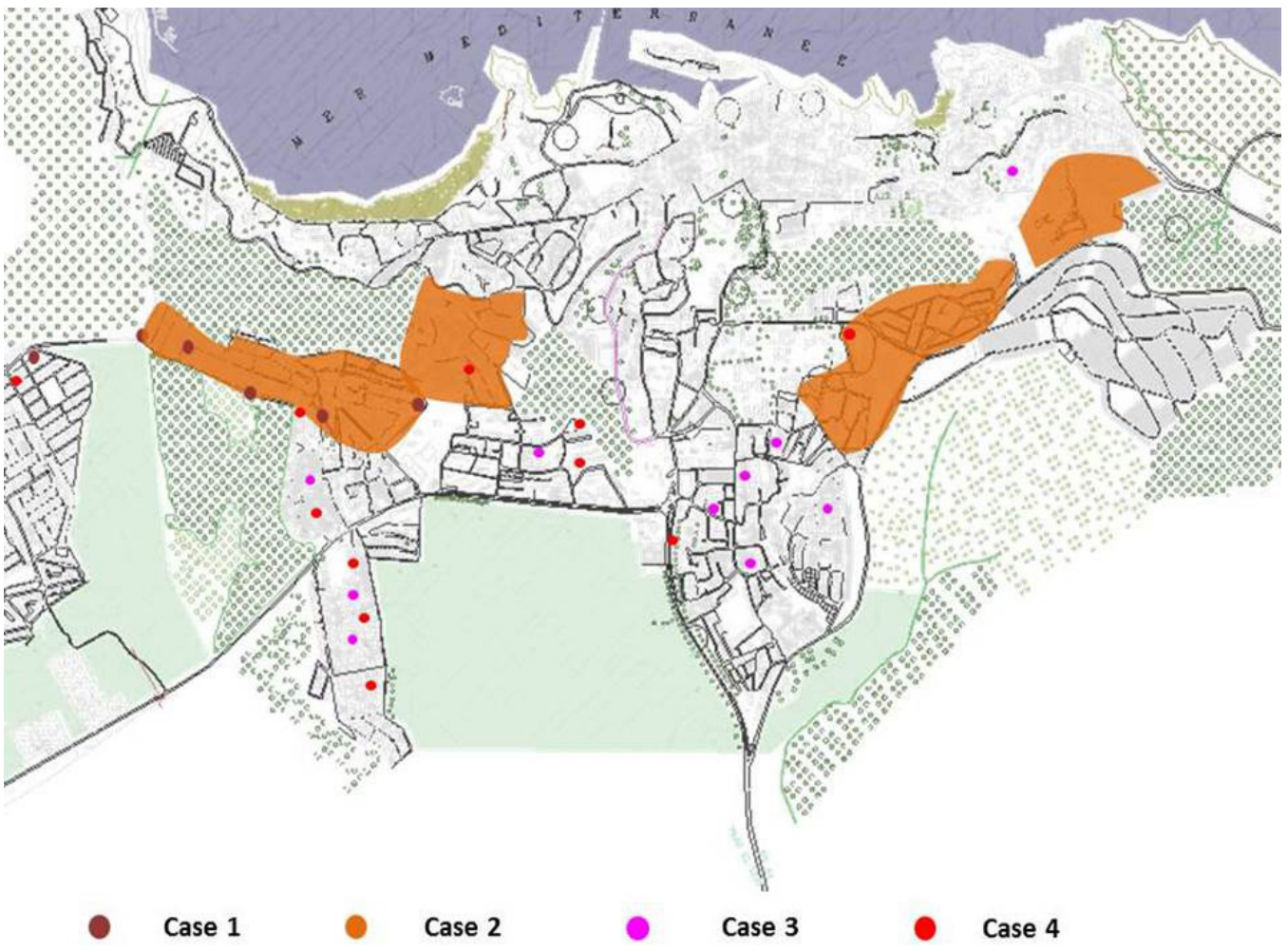

Fig. 9. Cases observed. Source: Author, 2021. 


\section{TABLE III}

The Number and Percentage of Each Case

Source: Author, 2020.

\begin{tabular}{|l|l|l|}
\hline Case & Number & $\%$ \\
\hline 1 & 5 & 1.25 \\
\hline 2 & 371 & 93.35 \\
\hline 3 & 10 & 2.51 \\
\hline 4 & 11 & 2.77 \\
\hline Total & 397 & 100 \\
\hline
\end{tabular}

limit of Gelass-south, in an urban environment, but with a particular quality that the topography offers: visual accessibility to a natural environment with Lake Oubiera appearing as a blue plane on the horizon. Visual contact is concentrated on the urban environment, while visual contact with nature is almost absent.

The generalisation of this typology of the four cases analysed to all the cases observed (535 constructions) made it possible to identify the percentage of each case with an elimination of constructions that cannot connect with the surrounding natural landscape due to urban and topographical constraints: 138 constructions (Table III). It can be noted that constructions that ensure visual contact with a particular natural landscape (sea, forest, lake) represent the highest percentage (93.35\%). While those which are in visual break with the natural environment, by introversion or by choice, indicate a low percentage $(2.51 \%$ and 2.77). Buildings that open onto all views without any particularities represent the lowest percentage $(1.25 \%)$ (Fig. 9).

\section{The Biophilic Behaviour of the Inhabitant: The Interpretation of the Relationship Between Domestic Space and Nature}

According to Tables 1 and 2, the biophilic behaviour of the self-constructing inhabitant is characterised by an approximation of the natural elements, inserting them into his/her domestic space for reasons of consumption, aesthetics and protection. Beyond this, the inhabitant does not hesitate to open his domestic space to natural landscapes, without particularities, for reasons of wonder and admiration in front of the beauty and complexity of nature and its diversity. When the landscape is particular, such as the sea, Lake Oubiera, the forest of Boulif, the biophilic behaviour takes on a new character, much more symbolic than aesthetic. The percentage of the negativistic behaviour of the self-constructing by inhabitant (5.28 \%) remains low in relation to the whole; it is perceived by the remoteness of this inhabitant from all the elements of his/ her natural environment (Table IV).
TABLE IV

The Biophilic Behaviour of the Inhabitant Source: Author, 2020.

\begin{tabular}{|l|l|l|}
\hline \multicolumn{2}{|c|}{ Nature in the domestic space } & \multicolumn{1}{c|}{ Behaviour } \\
\hline Usage & $\begin{array}{l}\text { Garden, vegetable garden, } \\
\text { fence, natural cover }\end{array}$ & $\begin{array}{l}\text { Utilitarian, naturalistic } \\
\text { and aesthetic }\end{array}$ \\
\hline $\begin{array}{l}\text { Visual } \\
\text { contact }\end{array}$ & Case 1 $(1.25 \%)$ & Naturalistic and aesthetic \\
& Case 2 (93.35\%) & Symbolistic \\
& Case 3 (2.51\%) & negativistic \\
& Case 4 (2.77\%) & negativistic \\
\hline
\end{tabular}

\section{Conclusions and Perspectives}

In the case of the city of El Kala, the relationship between man and nature is studied through the insertion of natural elements in the domestic space, one of the principles of biophilic design in architecture. On the one hand, urban space professionals of the city of El Kala do not seek to give a place to nature in the domestic space as an architectural and landscape component. On the other hand, the inhabitants attempt to compensate for the absence of natural elements in the domestic space with their creations in the unbuilt space. Moreover, self-constructors add another way of dealing with nature, where nature is used as a guiding factor in their constructions. The biophilic behaviour of the inhabitants towards nature as a whole is varied between utilitarian, naturalistic, aesthetic, symbolic and even negativistic.

Given this complexity, we can conclude that the biophilic design observed through the presence of natural elements in the domestic space of the city of El Kala, as well as its opening onto the surrounding natural landscape, is the result of an initiative of the self-constructive inhabitant, and not of the will or creativity of the professionals of urban space. Since it places nature at the centre of its preoccupations, the biophilic approach can lead to the highest level of protection of the natural environment of El Kala and human health, by adopting it as a principle and approach in the production of the urban and architectural space.

\section{Acknowledgement}

The author would like to thank Professor Sassia SPIGA for her valuable contribution. 


\section{REFERENCES}

1. Stauskis, G. Identifying Key Criteria for Quality Assessment of Landscape Architecture Projects. Architecture and Urban Planning, vol. 16, no. 1, 2020, pp. 5-11.

https://doi.org/10.2478/aup-2020-0002

2. Sevinç-Kayihan, K., Özçelik-Güney S., Ünal F. C. Biophilia as the Main Design Question in Architectural Design Studio Teaching. Megaron, vol. 3, no. 1, 2018, pp. 1-12. https://doi.org/10.5505/megaron.2017.59265

3. Kaplan, R., Kaplan, S. The Experience of Nature: A Psychological Perspective. Cambridge, New York: University Press. 1989, p. 340.

4. Ulrich, R. S. Aesthetic and affective response to natural environment. In Altman I., Wohlwill J. F. (eds) Behavior and the Natural Environment. Human Behavior and Environment (Advances in Theory and Research), vol. 6. Springer, Boston, p. 85-125. https://doi.org/10.1007/978-1-4613-3539-9_4

5. Scopelliti, M., Carrus, G., Bonaiuto, M. Is it Really Nature That Restores People? A Comparison with Historical Sites with High Restorative Potential. Front. Psychol. vol. 9, 2019, pp. 27-42. https://doi.org/10.3389/fpsyg.2018.02742

6. Stigsdotter, U. K., Ekholm, O., Schipperijn J., Toftager, M., Kamper-Jørgensen, F., Randrup, T. B., Scand, J. Health promoting outdoor environments--associations between green space, and health, health-related quality of life and stress based on a Danish national representative survey. Scandinavian Journal of Public Health, vol. 38, no. 4, 2010, pp. 411-417. https://doi.org/10.1177/1403494810367468

7. Ward, A., Arrighi, H. M., Michels, S., Cedarbaum, J. M. Mild cognitive impairment: Disparity of incidence and prevalence estimates. Alzheimer Dement. vol. 8, no. 1, 2012, pp. 14-21. https://doi.org/10.1016/j.jalz.2011.01.002

8. Wilson, E. 0. Biophilia and the conservation ethic. In S.R. Kellert and E. O. Wilson eds. The biophilia hypothesis, Washington, D.C.: Island Press, 1993, pp. 381-414.

9. Kellert, S. R. The biological basis for human values of nature. In S.R. Kellert and E.O. Wilson eds. The biophilia hypothesis, Washington, D.C.: Island Press, 1993, pp. 42-69.

10. Beatley, T. Biophilic Cities. In: Meyers R. (eds). Encyclopedia of Sustainability Science and Technology. New York, NY: Springer, 2020.

https://doi.org/10.1007/978-1-4939-2493-6_1033-2

11. Ebrahimpour, M. Proposing a framework of biophilic design principles in hot and arid climate of iran by using grounded theory. Civil and Environmental Engineering, vol.16, no. 1, 2020, pp. 71-78. https://doi.org/10.2478/cee-2020-0008

12. Totaforti, S. Emerging Biophilic Urbanism: The Value of the Human-Nature Relationship in the Urban Space. Sustainability, vol. 12, no. 13, 2020, pp. 54-87. https://doi.org/10.3390/su12135487

13. Hoyaux, A. F. De l'espace domestique au monde domestique. Point de vue phénoménologique sur l'habitation [From domestic space to the domestic world. Phenomenological point of view on housing]. In B. Collignon and J. F. Staszak (eds.) Espaces domestiques. Construire, habiter, représenter, Bordeaux: Editions Bréal, 2013, pp.33-45.
14. Chowdhury, S. N., Noguchi, M., Doloi, H. Conceptual Parametric Relationship for Occupants' Domestic Environmental Experience. Sustainability, vol. 13, no. 5, 2021, pp. 29-82. https://doi.org/10.3390/su13052982

15. Delbosc, P., Ceccaldi, A., Panaïotis, C., Bioret, F., Hugot, L. Unités paysagères fonctionnelles: outil d'aide à la planification territoriale [Functional landscape units: a tool to help with territorial planning]. Vertigo: la revue électronique en sciences de l'environnement, vol. 18, no. 3, 2018, pp.1-37. https://doi.org/10.4000/vertigo.23657.

16. Paquette, S., Poullaouec-Gonidec P., Domon, G. Le paysage, une qualification socio-culturelle du territoire [The landscape, a socio-cultural qualification of the territory]. Material History Review, vol. 62, 2005, pp. 60-72.

17. Kellert, S. R. Biophilia and biomimicry: evolutionary adaptation of human versus nonhuman nature. Intelligent Buildings International, vol. 8, no. 2, 2014, pp. 51-56. https://doi.org/10.1080/17508975.2014.902802

18. CNES/Airbus (2020). Data SI, NOAA, U.S. Navy, NGA, GEBCO Terra Metrics [online]. Maxar Technologies [cited 1.04.2021]. https://www.maxar.com

19. El Kala: Grands Atouts, petit ambition [El Kala: Big Assets, Small Ambition] [online]. Algerie 360 [cited 1.04.2021]. https://www.algerie360.com/el-kala-grands-atouts-petiteambition/

20. Belguidoum, S., Mouaziz, N. L'urbain informel et les paradoxes de la ville algérienne politiques urbaines et légitimité sociale [The informal urban and the paradoxes of the Algerian city urban policies and social legitimacy]. Espaces et sociétés, vol. 3, no. 143, 2010, pp. 101-116. https://doi.org/10.3917/esp.143.0101

21. Bachar, K. Une lecture de la loi relative à l'achèvement et la mise en conformité des constructions [A reading relating to the completion and compliance of construction]. RURAL-M Etudes sur la ville - Réalités URbaines en Algérie et au Maghreb, 2020 [online, cited 2.04.2021]. http://ruralm. hypotheses.org/1779

22. Matvejs, J. Private Space in Soviet Cinema: Case Study of Riga. Architecture and Urban Planning, vol. 14, no. 1, 2018, pp. 75-82. https://doi.org/10.2478/aup-2018-0010

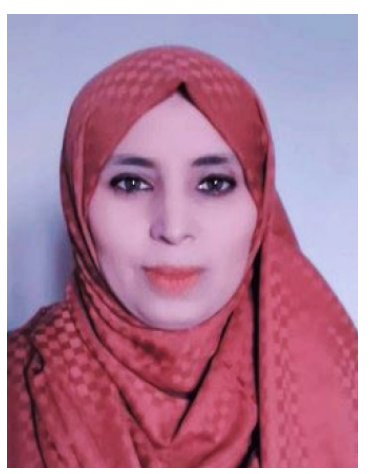

Fatima Zahra Djouad is an architect and urban planner who obtained her degree in architecture in 2007 and her Magister degree in Urban planning in 2010. She received a $\mathrm{PhD}$ in Urbanism (urban planning) in 2018 and is a member of the LAUE laboratory of the University of Annaba, Algeria. She is currently a Senior Lecturer at the University of Guelma, Algeria and participated in the research project "The implication of local assets and 
potentialities for the development of sustainable tourism: The case of the Guelma region". Her scientific interests focus on the interactions between the departments of architecture and urban planning of the Faculty of Science and Technology of the University 8 Mai 1945, Guelma, Algeria.

\section{Contact Data}

\section{Fatima Zahra Djouad}

Faculty of Science and Technology, University 8 Mai

1945, Guelma, Algeria

E-mail: djouad.fatimazahra@univ-guelma.dz 